\title{
Religion and Feminism in the Short Story of Alifa Rifaat—The Voice of the "Voiceless"
}

\author{
Nayera El Miniawi \\ Al Balqaa Applied University, Amman, Jordan
}

\begin{abstract}
This paper is an attempt to bring to the foreground a better understanding and appreciation of the work and impact of an Arab Muslim woman writer whose work, characters, thoughts, settings, and words sink very sensitively into the depth of being of her oriental women characters. They are very local and they reflect a typical oriental and distinct religious sentiment, along with an underlying predicament or suffering because of some lack in their love life, both emotional and sexual. This paper will attempt to analyze how the short story written by Alifa Rifaat (1987) deal with the thorny issues of religiosity and sexuality that might appear as two opposing poles, yet they mix and blend within same characters exposing different aspects of the human being living within dilemmas of personal needs and social dictates of tradition, taboo, and culture. For a non Arab reader, this should be an interesting and informative cross-cultural issue.
\end{abstract}

Keywords: Islamic feminism, voiceless women, oppression, body and soul, religion

\section{Introduction}

In the short stories of Egyptian writer Alifa Rifaat (1987), voiceless women are given a voice. They are portrayed in many cases as weak, submissive, and suffering, yet their "silence" suggests some kind of awareness and focus.

Rifaat typically employs a strategy of creating female characters who, while appearing to accept compliantly the prevailing images of women, strikingly subvert and revise those images. Through the stories of their own bodies, the female characters rewrite the stories that have allowed domination over their bodies, with their seeming compliance all the while disguising the subversive nature of their act. (Olive, n.d., p. 49)

It is interesting to see how these subdued women find outlets, escape or even strength in one thing or another. Some of them (actually several) do cry, and their tears bring awareness of their condition and protest to the reader. Others resort to religion, prayer, or even the supernatural, and these practices substitute for a lack or deficiency of emotional fulfillment and physical well-being.

\section{Alifa Rifaat, the Person}

Alifa is the pen name of Fatma Rifaat (1930-1996), who was born in Cairo, Egypt. Her father was a well-to-do architect. She was raised in the countryside and demonstrated an early talent for writing. By the age of

Nayera El Miniawi, associate professor, Princess Alia University College, Al Balqaa Applied University. 
nine, she had written poetry describing the spirit of despair in her village. Rifaat attended Misr al-Jadidah primary school and then the Cultural Centre for Women for her intermediate education. She also attended the British Institute in Cairo from 1946 to 1949.

Alifa's father forced her to marry a mining engineer at an early age, but their marriage remained unconsummated, and lasted only eight months. Then, in 1952, Rifaat married her cousin, a police officer whose work provided her with the opportunity of travelling around different provinces in Egypt, which was reflected in her fiction. She began writing again and published a short story in 1955, adopting the pen name of Alifa. She continued writing until 1960, when her husband made her promise to stop, but she continued avidly reading literature, science, astronomy, and history. She did not resume writing until 1973, after falling seriously ill for psychosomatic reasons.

Beginning in 1974, Rifaat published a number of short stories in a literary journal, followed by a collection of short stories, Eve Returns With Adam to Paradise (1975) and a novel: The Jewel of Pharo (1978). Throughout the 1980s, following the death of her husband, she continued to publish short stories. In 1984, she won the Excellence Award from the Modern Literature Assembly. She contributed nearly 100 short stories to Arabic and English magazines. Her novel, Girls of Baurdin, was published in 1995. Her best known work is A Distant View of a Minaret, a collection of short stories published in 1983.

\section{Feminist Themes}

Rifaat's short stories are well known for portraying the dynamics of female sexuality, relationships, and loss and suffering in rural Egyptian settings. In spite of tackling some controversial feminist subjects, her women protagonists remain religiously faithful and adopt silent, passive attitudes towards the injustices of patriarchal society.

Critics have been quick to note that Rifaat's brand of feminism is distinct from that of Arab women writers from a more intellectual or sophisticated background, many of whom have drawn inspiration from the women's liberation movement in the West. In contrast, the revolutionary quality of her works arises from a direct and spontaneous battle with the traditional outlook that finds contradictions in being both a sensual woman and a devout Muslim. In her stories, these two aspects coexist.

Rifaat's characters are very local, and her narratives exist in spaces where Islam, and all its traditional social practices in a patriarchal society, rest alongside female sexuality, pleasure, and pain-merging into a strong fundamental female identity. While religiosity and sexuality might appear as two opposing poles, in Rifaat's stories, they blend within the same character to expose different aspects of the human being living the dilemmas of personal needs as opposed to the social dictates of tradition, taboo, and culture. Through her short stories, Rifaat expresses a revolt against patriarchal dismissal of female sexuality.

The women characters in Rifaat's stories are enveloped with an air of righteousness. No matter how mistreated and how deprived they are, they never resort to sin, immorality or a physical/sexual relationship out of wedlock. On the other hand, their male counterparts are most often blamed and condemned for the female characters' frustrations and the unhappy outcomes in the stories.

Many are the incidents when we witness the women characters praying, or doing their ablutions as a purification measure before prayers. Their use of language related to God and religion is ample. The voice of the 
muezzin calling for prayers is very frequently heard in the stories. Her characters and plots are brought to life against the backdrop of a palpable, clearly delineated Islamic/Arab environment.

It is useful to look into the author's own life to find out why these simple, frustrated, and abused women are of major interest to her, for autobiographical elements are evident in many of her stories.

Rifaat herself was subjected to typical patriarchal oppression and psychological—if not physical, as in the case of her protagonists—-abuse. She was first silenced and victimized by her father who punished her for writing her first short story when she was only nine years old. When she wished to continue her education, she was again punished by being forced into an undesirable marriage at an early age. When this marriage failed, she was forced to marry her cousin, a police officer who discouraged her from writing. During this time, she wrote and published under a pseudonym. However, in 1960, when her story, "My World of the Unknown”, attracted attention, her husband demanded that she stop writing altogether or he would divorce her. He made her promise not to publish her works. She kept this promise for a period of around 15 years, writing only in secret, locked in the bathroom. Later, when she fell ill for psychosomatic reasons, she asked her husband to release her from her promise. She found out that after so many years of self-sacrifice on her part, he did not even remember making her promise. She then resumed her writing endeavors as a form of therapy, but it was only after her husband's death that she was able to publish her first collection of stories (Mitra, 2010, p. 4).

\section{The Stories}

\section{“A Distant View of a Minaret” (1987)}

"A Distant View of a Minaret" is the first short story in Rifaat's collection carrying the same title. The story opens with a description of a husband and wife making love. The woman seems engrossed in observing various details of the room and her body, basically how she observes and feels about the room, her husband, herself, and their life together. She is obviously not aroused or fulfilled by the intimate moments while her husband is just satisfying himself. After the lovemaking is finished, she goes to perform her ablutions and prays. The five daily prayers required by her Muslim faith become her solace; they give purpose to what seems to be an emotionally and physically deprived life.

The solitary minaret is a symbol of the female character herself, a lonely, unhappy woman in an unfulfilled marriage, who is caught between two overpowering blocks: a patriarchal culture which inhibits woman's sexuality and women's desire to be sexually fulfilled... This juxtaposition brings out the contradiction between male attitudes toward women's sexuality and women's rights to loving and kind treatment in marriage as prescribed by The Quran. (Nkealah, 2008, p. 27).

The Quran sees sexual union as the very foundation on which is established deep human connections central to the formation and survival of enduring communities... The Quran grants to men and women analogous sexual natures, recognizing thereby women's rights to sexual fulfillment as much as men's right... The Quran's liberal and inclusive sexual ideology has been misrepresented and misused in the practices of Muslim patriarchies through history. (Asma Barlas, “Believing Women” in Islam: Unreading Patriarchal Interpretations of The Quran (2002), pp. 135-136, as cited in Mitra, 2010, p. 1)

After finishing her prayers, the lonesome, frustrated woman protagonist goes to sit for awhile on the balcony by herself. Just like her, the minaret is alone. Later, when the protagonist goes back to her bedroom carrying a cup of coffee—as usual—for her husband, she finds out that he has died in bed after their lovemaking. To her own 
surprise — and the reader's amazement—she sits down to drink the coffee that she had prepared for her husband, showing no signs of sadness or bereavement, but rather a feeling of relief.

\section{“Bahiyya's Eyes” (1987)}

"Bahiyya's Eyes" is another story in the same collection, also featuring an oppressed protagonist. "Her [Bahiyya's] life seems... nothing more than a series of endless struggles and pain, void of any satisfaction or joy... she mentions the beatings she got from her father, the sexual dominance of her husband...” (Salti, 1991, p. 110). What is different in this story is that, it illustrates that the oppression suffered by women is not always due to men. A woman can be oppressed by a father forcing her to marry against her will, or by an unsupportive husband, but also other women can be unjust and oppressive.

The theme of female sexuality is explored through the eyes of an innocent young girl, Bahiyya, who learns about the process of conceiving by observing animals, and noticing the similarity between their mating and that of humans. Through a process of observation and self-education, she understands the dynamics of sexuality. She then proceeds to create her parents out of mud.

"Why don’t I make my mother and father.” I made both of them with arms and legs and a head and then I put a thing like a cat's tail on my father. I didn’t know what to put for my mother, so I lifted my galabia and didn’t find anything there except for something lying there between two leaves... something like a sort of mulberry. (Rifaat, 1987, p. 9)

Young Bahiyya's observations, deductions, and creativity will have devastating results when, ironically, she is punished at the hands of women (not men!). A group of older women discover her while she is making the mud figures resembling a man and a woman, showing their sexual organs. They catch her and forcibly circumcise her in an operation of FGM (Female Genital Mutilation). The bewildered nine-year-old girl will retell her story while her psychological wounds will never heal.

Bahiyya describes her punishment:

I found the women coming in and gathering round, and then they took hold of me and forced my legs open and cut away the mulberry with a razor. They left me with a wound in my body and another wound deep inside me, a feeling that a wrong had been done to me, a wrong that could never be undone. And so tears welled up in my eyes again. (Rifaat, 1987, p. 9)

This is an example of the physical and psychological pain of the suffering female. Yet, in this story, like Rifaat's other stories, “The blame for women’s situation... is never directed towards God or Islam... [Rifaat] rather blames society for treating her unkindly...” (Salti, 1991, p. 111). The female characters and the writer herself do not resent the biological and social roles assigned to women, such as childbearing and childrearing, but resent the lack of encouragement and appreciation that they receive from society.

We hear Bahiyya saying:

I'm not crying now because [I]... regret that the Lord created me a woman. No, it's not that. It's just that I'm sad about my life and my youth that have come and gone without my knowing how to live them really and truly as a woman. (Rifaat, 1987, p. 11)

Alifa Rifaat views women’s sexuality as natural and God-given, not negative or taboo. The writer supports her protagonist by replacing the traditional association of female sexuality and darkness with an image of purifying fire that leaves Bahiyya “safe as Abraham” and having “reached God” (Olive, n.d., p. 47). 
Bahiyya is also a symbolic name that stands for Egypt. By choosing this name for her protagonist, Rifaat seems to be signaling that the girl's problems are typical for Egyptian females. The name, Bahiyya, has many meanings. It refers to a beautiful and charming woman, eager to please and to be loved. A woman named Bahiyya is sensitive and prepared to make considerable efforts to ensure harmony prevails; she expects her family to provide the security and protection she needs. She is also religious and possesses an inner strength. It is not known if Rifaat was aware of all these connotations of the name, but they describe her character amazingly well (Retrieved from http://www.first-names-meanings.com/names/name-BAHIA.html).

The story, “Bahiyya's Eyes”, like Shaharazad's storytelling in The Arabian Nights (2009), saves the life of the narrator. Bahiyya, who has always been silenced, hurt, and oppressed, suddenly acquires a voice when she pours out her life story in a letter to her daughter.

Bahiyya's narrative is a litany of her body, a rehearsal, (?) powerful act of reclaiming her body from the plethora of violations done to it. Whether it be the denial of access to the natural and social worlds, the denial of freedom to space and movement, the denial of sexual fulfillment, the denial of self-determination-all these elements are detailed in the narrative parts of Bahiyya's body, her body and words become one in the story. (Olive, n.d., p. 48)

\section{"Badriyya and Her Husband" (1987)}

This story also focuses on a dissatisfied wife, Badriyya, who is manipulated by a devious, outlaw husband, Omar. Theirs is an unconsummated marriage that lasts only for one month before he is taken to prison. After a year or more, Omar is released, but he is seen exploiting his wife for financial gains while continuing to neglect her physically and emotionally. Engulfed in his male-dominant world, Omar is a worthless husband who lies to his wife and who never ever sleeps with her. Thus, his criminality is connected to his failure to fulfill his wife.

\section{“Mansoura” (1987)}

While Badriyya is sexually deprived, Mansoura is sexually exploited by Hamdan, a man who has the financial means to manipulate her and her husband's life. She desperately tries to preserve her honor and love for her husband who is oblivious to what is going on in his household during the long hours he is away, working hard to provide a better life for his beloved Mansoura.

Significantly, Mansoura's name means "the victorious one" in Arabic. This is a case of heavy irony since she ends up drowning in the village canal. The previously beautiful Mansoura's body is found bloated and decayed beyond recognition. It can only be identified by the bangles seeming to strangle her bloated wrists in a state of death. Her drowning poses the question of whether women will surrender to death, but Rifaat's answer is an unequivocal "no". To make this point, she brings the supernatural into play in the story to wreak revenge on Hamdan. While he is at work lifting huge pipes in a construction project, one of the pipes drops on him in a most mysterious manner. His last words are: "Mansoura!” alluding to the female power that will later be invoked by all the working men calling out Mansoura's name as a mantra that induces courage and resilience.

This is one example of the fact that although most, if not all, of Rifaat's female characters are portrayed as helpless, deprived, and submissive, still they possess an amazing inner strength that springs out of their weakness in most unconventional ways.

"My World of the Unknown" (1987)

Another landmark story is the one entitled "My World of the Unknown", where again an emotionally and 
sexually dissatisfied wife is the main focus; she is also the narrator. This woman strangely enough finds solace and fulfillment in a sexual relationship with a snake. It is interesting to observe that the snake is a female one, thus depicting the woman's love relationship as a lesbian liaison.

Here the feminist, sexual, supernatural, and spiritual all blend together. The beautiful serpent turns out to be a genie (jinn) in disguise. Though this lends an air of exoticism to the woman's relationship, she-like all Rifaat's female protagonists-is never depicted as engaging in adultery or sin. On the contrary, the sexual is transformed into a spiritual cure. The snake-lover assures her beloved that "the eye of God will see us; He alone will know what we are about and He will watch over us... I have wedded you, so there is no sin in our love” (Rifaat, 1987, pp. 72-73). The snake-lover then invites the wife to join in a Quranic prayer. Thus, even this unusual homosexual relationship is colored by unique spiritual/religious overtones that would possibly render the illicit sacred and sinless.

A sheikh, a man of religion, is invited to the house to chase away snakes, since Sufi Rifa'ya sheikhs are known to have such powers. He accepts the gender of the narrator's spirit visitor, and "subtly gestures toward a physical intimacy between the two, and emphasizes the situation as within the plan of God. Rifaat's text harnesses the greater complexity and freedom of Sufi attitudes to human sexuality as well as mystical communion with the world of spirits" (Mitra, 2010, p. 11).

The narrator of "My World of the Unknown" becomes "aware of her sexuality in a series of dream encounters with a supernatural spirit in the form of a female snake" (Mitra, 2010, p. 8). The snake arouses, in the protagonist, the most exquisite sensual awakening that she perceives and acknowledges as love. This state of bliss lasts until her husband kills the snake in an act of violence attributed to the male world as opposed to the beauty, ecstasy, and serenity of the female realm. The husband's violent and unnecessary killing of the snake breaks the pact agreed between the lovers that snakes will not be killed in their home. This brings the story to a sad end, for as a consequence of the husband breaking the pact, the family has to leave the house.

The author has successfully braided together Arab folklore with the classical myth of the snake as a symbol of temptation, in order to portray a wife's subconscious desire for sexual satisfaction without violating the framework of marriage. Her lover is a snake, not a man; thus, no sense of sin is involved. "Female homosexual desire can be legitimately explored without crossing the boundaries of what may be determined as transgressive- outside 'the limits prescribed by God', or in other words-'quite simply, a sin”” (Mitra, 2010, p. 10).

The she-serpent says tellingly: "Perfect beauty is to be found only in woman... so yield to me and I shall let you taste of undreamed of happiness" (Rifaat, 1987, p. 75). The woman describes her feelings in response: "She stretched out her fingers to caress me, while her delicate mouth sucked in the poisons of my desire and exhaled the nectar of my ecstasy, carrying me off into a trance of delicious happiness” (Rifaat, 1987, p. 75).

"Love and sex outside the boundaries of marriage is no part of the scenery of [Rifaat's] stories. For her, there is nothing romantic about adultery: it is, quite simply, a sin” (Rifaat, 1987, p. viii). This is one of the strongest religious manifestations and adherences within Rifaat's stories.

"My World of the Unknown" tells a completely different story than that of Adam and Eve. While the Judeo-Christian version of this story blames Eve for man's expulsion from paradise, in Rifaat's rendition, we find that the man, by killing the snake, causes the woman to be expelled from paradise, an imaginary Garden of Eden within the boundaries of her self-made unknown world. Here, the husband becomes another embodiment of 
patriarchal violence, while the protagonist/wife/narrator discovers, like the legendary Cleopatra, the possibility of sexual pleasure outside of heterosexuality.

This analysis is valuable in a number of ways: in emphasizing that a feminist vision like Rifaat's is not necessarily influenced by Western feminism; in noting the complexity of attitudes toward human, especially female, sexuality in Islam and tracing the contours of the tradition that she embraces as well as critiques. (Mitra, 2010, p. 10)

\section{Why a Snake?}

In classical mythology, the snake usually is a symbol of temptation, but in the Middle East, its connotations are more subtle.

In the mythic tradition of the Near East, the serpent carries complex symbolism usually associated with fertility, fecundity and prosperity. Its association with goddesses, also, is striking. In Egypt, from the ancient times, the serpent has been worshipped as a goddess of good. This wealth of suggestions has been worked into Rifaat's narrative in its quest for a legitimate space of a homoerotic desire. (Mitra, 2010, p. 12)

\section{Breaking the Code of Silence}

When "Arab women writers talk about their lives this is important because they provide a 'voice' for the 'voiceless' illiterate and working class women [who] otherwise would not have been heard or represented" (Golley, 2007, p. 112). The writer uses varied voices to verbalize words, thoughts, and hopes of many of the women. "Rifaat's characters resort to silence as a means of self preservation" (Nkealah, 2008, p. 19). The silence of women is something that is forced on them through the value system of patriarchal ideology. "Silence" becomes a coping mechanism, an acquired habit and a protective shield.

In the short story “A Distant View of a Minaret”, the wife's voice of sexual desire and fulfillment is silenced by her husband. She recalls her desperate attempts to satisfy her sexual needs and to express such wishes openly. Her inability to discuss openly her desires shows a code of "silence by which sexual matters between them remain a forbidden subject” (Nkealah, 2008, p. 25). As usual at such times, she felt that he inhabited a world utterly different from hers, a world from which she had been excluded. When they first married she had tried to will her husband into sensing the desire that burned within her, but she has been too shy and conscious of conventions to express such wishes openly. She submits in silence to his sexual act yet her mind is taking note of the cobwebs on the ceiling, her toenails that need trimming, etc.

This code of silence enveloping the subject of sex-even between married couples—leaves the woman character trapped in a situation in which she can express her self to no one-not her husband or even her women friends. She is thus reduced to passivity. "Here sexuality becomes passive not by choice or nature but through the domineering selfish act of her husband” (Nkealah, 2008, pp. 26-27).

This sexual passivity and silence leave the woman dissatisfied and sadly quiet. The Islamic practice of praying becomes the only constant in her life. For this oppressed woman character, her five daily prayers are the highlights that mark, divide up and give meaning to her life. From an Islamic Feminism point of view, religious practices can possibly provide women with the solace they need, as is the case of the woman in “A Distant View a Minaret”.

"Rifaat uses religious imagery to support the woman's right to her sexuality in this case by paralleling the husband's denial to his wife of sexual pleasure with the gradual closing off to her view of the city's many minarets” (Olive, n.d., p. 48). 
"By shifting the sex/death connection from female (death in life for the wife) to male, Rifaat turns the story of a seemingly passive woman, her body controlled and confined, into a radical narrative” (Olive, n.d., p. 48).

Edward Said has pointed out that resistance requires "work[ing] to recover forms already established or at least influenced or infiltrated by the culture of empire” (Said, 1993, p. 210). Rifaat shows women’s resistance to the handicaps imposed on them by being silenced. She becomes the "infiltrator in order to alter the forms that work against the lives of women. She rewrites those images of women that have been most destructive to their lives in an attempt to improve the lives of contemporary women” (Olive, n.d., p. 49). Rifaat’s stories can be seen as an attempt to read and teach other women. Arab women's writings focus on taboo subjects such as virginity requirements, sexual pleasure, abortion, and the female body as a whole, which have generally been silenced. Developing diagnostic awareness of the problem constitutes the first step towards giving these silenced women a voice with which to revolt and reform.

In “Bahiyya’s Eyes”, a woman undergoes forceful cutting out (physically and psychologically) and eventually adopts a code of silence.

Rifaat in this story shows not only the viciousness with which matters of sexuality are suppressed in traditional society, but also that circumcision is one of the means by which social control over women is exerted, thus forcing them into silence. Women’s “silence” remains a major subject of Arab feminist criticism. (Nkealah, 2008, p. 24)

Women’s voices are not just “silent” but have been "silenced”, “for it is not just that women do not speak: often they are explicitly prevented from a speaking, either by social taboos and restrictions or by the more genteel tyrannies of custom and practice” (Nkealah, 2008, p. 24).

Thus, by writing fiction in which women express their wishes and feelings, women writers are giving other women a "voice". The very act of writing challenges the patriarchal ideology that the domain of language is masculine. By daring to venture into the male domain of writing, women writers succeed in negotiating power with men.

\section{Islamic Feminism}

Feminism in the Arab word and Middle Eastern countries should not be confounded with Western concepts of feminism. Arab feminism emerged in the latter part of the 19th century and acquired true recognition in the past fifty years or so. “The term 'feminism' was used in France in the late 1880's by Hubertine Auclert, to criticize male predominance and to make claims for women's rights and emancipation as promised by the French Revolution” (Badran, 2009, p. 242).

Cooke (1988) explained what is meant by feminism and feminist by saying:

I use feminist to refer to women who think and do something about changing expectations for women's social roles and responsibilities... Feminism is... an epistemology. It is an attitude, a frame of mind that highlights the role of gender in understanding the organization of society. Feminism provides analytical tools for assessing how expectations for men's and women's behaviour have led to unjust situations, but not necessarily only for women. Feminism seeks justice wherever it can find it. Feminism involves political and intellectual awareness of gender discrimination... (p. ix)

The term appeared in English in the first decade of the 20th century in Britain, then in the United States by the 1910s. "In the early 1920s it was used in Egypt in French and in Arabic as 'nisa'iyya”” (Badran, 2009, p. 308). 
Although the term originated in the West, feminism is not just Western. Arab feminism is not French or Western. The 1960s, 1970s, and 1980s have seen a spread of feminist works in Egypt and in the Arab World. Then the term “Islamic Feminism” began to appear in the 1990s. As an example, “Saudi Arabian scholar Mai Yamani used the term in her 1996 book, Feminism and Islam” (Badran, 2009, p. 243).

“Islamic feminism transcends and eradicates old binaries. These include polarities between 'religion' and 'secular' and between 'East' and 'West'” (Badran, 2009, p. 245). There seems to be an overlap between religious and secular feminisms. Secular feminism (or simply feminism) also uses Islamic arguments in asking for women's rights of education, work, and political rights.

Alifa Rifaat maintains through her writings a "complex relationship with the culture of her faith and her location within a distinctively Arab feminist tradition that is independent of Western feminism” (Mitra, 2010, p. 9). Salti (1991), an Arab-American writer and critic of Arabic literature, commented: “Alifa Rifaat may be thought of as belonging to that group of Arab feminists who advocate a view of women which does not stray from Islam” (p. 108).

Rifaat had a deep knowledge of The Quran which, if read in the proper way, would guarantee Arab women a much better social position that comes very close to equality with men. In this regard, Cooke (1988) commented that wherever Muslim women offer a criticism of some aspect of Islamic history or attitudes, they do so on behalf of all Muslim women as it is the right of all women to enjoy equality and fairness with men in a just society. Islamic feminism is not "an identity as much as it is an attitude and intention to seek justice and citizenship for Muslim women” (Cooke, 1988, p. 61). “The term 'Islamic Feminist' invites us to consider what is meant to have a difficult dual commitment: on one hand, to a faith position and on the other hand, to women's rights both inside the home and outside” (Cooke, 1988, p. 59).

Muslim feminists are not blind imitators of Western models but are focusing on women's roles inside their religion-bound societies. Johnson-Davies makes an excellent point when he says that "Rifaat's revolt... is merely against certain man-made interpretations... that have grown up over the years and remain unquestioned” (Rifaat, 1987, p. viii). Rifaat seems to be taking a fundamental feminist position by attempting to rewrite a male-centered history. On the other hand, she is also able to draw clear distinctions in her mind between God's will and the will of men. She never touches on atheism, yet she advocates a strong stand criticizing the traditional male role in some Arab societies.

Rifaat's intentions of writing about women's lives and sexuality are inspired by “a woman’s Islamic right to a fulfilled emotional and sexual life” (Olive, n.d., p. 44). In many instances, women are torn between what they wish for and their grim reality. They are then torn between "dream and reality". "In the context of this discrepancy, marriage becomes martyrdom in order (for the woman) to remain a 'decent women' in the eyes of society” (Shaaban, 2009, p. 163).

Rifaat has tried to focus on an independent identity for women within the context of Islam, without adopting a Western or secular stand which would be a departure from recognized social and religious norms. In Rifaat's stories in A Distant View of a Minaret, many of the characters are seen doing their prayers and using religious words, the name of Allah and words of prayers in a quite evident manner. The call for prayers coming from mosques is frequently heard. 
Rifaat shows the many wrongs that are practiced against women in her society while still she adheres to the Islamic way of life as an ideal. Most of her main characters are women suffering marital problems or unfavorable life conditions because of widowhood, negligence or interference by male members of their society and/or family. "Rifaat presents characters who benignly accept prescribed norms of female behaviour in both marriage and sexuality” (Nkealah, 2008, p. 25).

Alifa Rifaat is considered by critics to have "a unique style and outlook on life [which] earned her a place in Arab Literature not only as a feminist, but also one of those new writers who are slowly moving away from the eloquent yet occasionally alienating classical Arabic, and towards a language that can be understood more easily by Arab readers. Her linguistic contribution, her courage to write about things that need to be discussed yet are often left unspoken, and her realistic and genuine style have done much to improve the situation of Arab women as a whole, and have given a boost to an already growing feminist movement in Egypt” (Salti, 1991, p. 112), and the Arab World.

Rifaat uses colloquial words, expressions, and phrases instead of writing exclusively in classical Arabic. This linguistic trait allows her narrative to flow more easily and adds a quality of realism to her stories. Rifaat is considered one of the Arab women feminist writers of the 1970s. This was a time and an impact that contributed to the Egyptian and Arab literary traditions. For Arab feminist writers, "the movement between the colloquial and the standard in narrative and dialogue helps to raise and endorse a female point of view" (Seymour-Jorn, 2011, p. 149).

Those Arab woman writers do not claim that women's oppression is simply a result of men or a patriarchal system, but they help generate:

A complex critical discourse that illuminates how gender ideologies combine with political oppression and a host of economic issues (un- and underemployment, inflation, housing shortage, and inadequacy of public services) to constrain the lives of women, to drive them to eccentricity, or an alienated point of view. (Seymour-Jorn, 2011, p. 149)

Their women protagonists are representing women with a range of issues that affect their existence, their families, and their societies.

What is quite evident in Rifaat's style is the obvious use of Muslims' daily language of praise and thanks to Allah. For example, in the story of "Bahiyya's Eyes", the story opens with "we praise him and thank him for his favour for whatever he decides” (Rifaat, 1987, p. 5). Bahiyya constantly uses religious utterances such as: “Allah’s will”, “Allah’s hands”, “Allah have mercy on her”, “Allah forgive me”, and “Allah bless you”. These are not true prayers as much as they are habits of speech which nevertheless exhibit a religious frame of mind and inclinations. By using these terms in all of her stories, Rifaat is placing her stories in a typical Islamic setting.

In another story, "Mansoura”, the laborers end their working day with prayers. And in "The Kite” (Rifaat, 1987), the wife who does not know how to perform the gestures and recitation of the daily prayers would stand behind her husband just following the gestures of prayers.

Rifaat's women protagonists, like herself, find themselves victims of oppressive men. These women challenge the existing negative models of women. Women writers, such as Rifaat, constitute a challenge to the existing set of negative images of "women in history and in popular stories and myths. This challenge 
involves taking refuge in that heritage itself and extracting from it 'anti-myths' that represent positive or at least more nuanced images of women" (Seymour-Jorn, 2011, p. 145). Thus, the wife in "My World of the Unknown" becomes a strong-willed and fulfilled woman when she associates herself with the mythical world of the jinn. Mansoura, as an apparition of a dead, abused, and raped woman, becomes a legendary figure, who lends support to men.

Our writer has drawn her characters based on:

An Egyptian and Arab heritage, Sufi writings, The Quran, popular tales, and local beliefs about jinn and other supernatural creatures to reinforce a sense of cultural rootedness while inspiring an exploration of issues of personal freedom and desire and the reconsideration of personal and social realities. (Seymour-Jorn, 2011, p. 145)

Alifa’s settings might vary from:

Simple huts in the rural areas to apartments in city or urban set ups. But one common feature in her fiction is the need of her women characters to be free and to liberate themselves from the social constraints that have chained them since their birth. (Salti, 1991, pp. 109-110)

The characters in the works under discussion have helped shatter the negative image that the West often has of the Arabs—-men and women. These stories have also shed light on the affinities shared by women all over the world.

In the stories we have mothers, wives, daughters, lovers, etc.. These characters highlight women's suffering in societies that differentiate between the men's world and the women's domain. It is a distinction between the public and the domestic. Through autobiographical writing, women find a means of survival. Doing that enables them to find a "voice".

Some of the characters are educated while others are illiterate. These characters represent as well different social classes: lower, middle, upper, and working classes.

The women in these stories have a voice that echoes two voices: One is the personal and the other is one immersed in its own environment and society. The family is a major nucleus in our author's stories. The family remains a pivotal social unit in Arab countries. That is why the woman figured in each of the stories would weave her life story around her family and her family relationships.

Rifaat's fiction frankly addresses women's emotional and sexual lives. Among her stories one finds plots about clitorectomy, social expectations of virginity, women's sexual dissatisfaction within marriage. The underlying motifs in her stories powerfully subvert the prevailing beliefs and practices that Rifaat feels take away women's original sexual rights under Islam.

Alifa Rifaat says about herself the following:

When I married I found my sexual life unfulfilling because nobody talked to me about the subject or taught me anything; I believe there should be more education for women, even if only through books. In my view, it is wrong to look to the West for sexual education for young people. Our society does not allow us to experience sex freely as Western women may. We have our tradition and our religion in which we believe. (Gale Literary Database, Cross Database Search, 2002, p. 23)

\section{Conclusions}

The short stories delve into the particular, but they draw interest that soars with the works to the level of the universal when the issue is basically an answer to a question of how far do some women suffer due to the 
insensitivity of a typical patriarchal society. How far are their voices silenced? How do they express their resentment? How much are they influenced by basic adherence to religion and spirituality? These were the issues dealt with and highlighted in the present research paper.

Alifa Rifaat is an Arab, Egyptian Muslim writer whose work is perhaps better recognized, appreciated, and studied in the West than it is in the Arab world. This paper contributes in shedding more light on a writer who has written only in Arabic and had to fight many odds until her stories saw the lights of publication.

This research work has developed a better understanding of how religious adherences and practices, which are sublimely spiritual, as well as their opposite of sexuality, lovemaking, or love needs are present with such prominence in the life and characters of Alifa Rifaat's stories.

This paper has examined these issues as they appear in her stories from a feminist point of view. The interesting thing here is that this critical approach should be part of a relatively modern new school of criticism called "Muslim Feminism", which is relevant to a writer who read no English and has written only in her native language-Arabic, reflecting a freshness and purity of style that was not affected or influenced by any foreign exposure. Doesn't her work warrant this effort?

In conclusion, this critical work would be of benefit to students, scholars, and readers who are interested in literature in general, but more so to those interested in Arab Women Writers who have an eye on feminism, Muslim Feminism, woman's studies, and an interest in cultural issues and in polarities within the human being of something like religion vis a vis sexuality.

\section{References}

Afzal-Khan, F. (1997, Spring). Introducing a new course: Muslim women in twentieth-century literature. NWSA Journal, 9(1), 76-88.

Afzal-Khan, F. (Ed.). (2005). Shattering the stereotypes: Muslim women speak out. M.A., USA: Olive Branch Press.

Al-Ali, N. S. (1995, Autumn). Gender writing/writing gender: The representation of women in a selection of modern Egyptian literature. World Literature Today, 69(4).

Ashour, R., Ghazoul, F. J., \& Reda-Mekdashri, H. (Eds.). (2008). Arab women writers: A critical reference guide, 1873-1999. Cairo and New York: The American University in Cairo Press.

Badran, M. (2009). Feminism in Islam: Secular and religious convergences. USA \& England: One World Publications.

Cohen-Mor, D. (2005). Arab women writers: An anthology of short stories. Albany: State University of New York Press.

Cooke, M. (1986, Spring). Telling their lives: A hundred years of arab women’s writings. World Literature Today, 60(2), 212-216. Retrieved from http://www.jstor.org/stable/40141684

Cooke, M. (1988, Spring). Prisons: Egyptian women writers on Islam. Religion \& Literature, 20(1), 139-153. Retrieved from http://www.jstor.org/stable/40059371

Cooke, M. (2001). Women claim Islam: Creating Islamic feminism through literature. New York and London: Routledge.

El Tahawy, M. (2012). Why do they hate us?. Foreign Policy, 193.

Fayad, M. (1995). Reinscribing identity: Nation and community in Arab women’s writing. College Literature, 22(1), 147-160. Retrieved from http://www.jstor. Org/stable/25112170

Gale Literary Database, Cross Database Search. (2002). Fatma Abdalla Rifaat (1930-1996). Contemporary Authors, $19(1), 23$. Retrieved from http://www.jstor.Org/stable/25112172

Golley, N. A.-H. (Ed.). (2003). Reading Arab women's autobiographies: Shaharazad tells her story. Austin, USA: University of Texas Press.

Golley, N. A.-H. (Ed.). (2007). Arab women's lives retold: Exploring identity through writing. Cairo, Egypt: The American University in Cairo Press.

Haywood, J. (1985). Distant view of a minaret and other stories by Alifa. World Literature Today, 59(2), 313. Retrieved from http://www.jstor.org/stable/40141650 
IIkkaracan, P. (Ed.). (2000). Women and sexuality in Muslim societies. New York: Women for human rights (WWHR).

Jamal, A. (2004). Women and sexuality in Muslim societies. P. Ilkkaracan (Ed.). Resources for Feminist Research, 31(1/2), 9, 56.

Mitra, I. (2010). There is no sin in our love: Homoerotic desire in the stories of two muslim women writers. Tulsa Studies in Women's Literature, 29(2), 311-329.

Nkealah, N. (2008). Reconciling Arabo-Islamic culture and feminist consciousness in North African women’s writing: Silence and voice in the short stories of Alifa Rifaat and Assia Djebar. Tydskrif Vir Letterkunde, 45(1), 19-41.

Olive, B. A. (n.d.). Writing women's bodies: A study of Alifa Rifaat's short fiction. Minnesota: Concordia College.

Rifaat, A. (1987). Distant view of a minaret and other stories. (D. Johnson-Davies Trans.). USA: Heinemann Educational Publishers.

Said, E. W. (1993). Culture and imperialism. New York: Knoft.

Salti, R. M. (1991). Feminism and religion in Alifa Rifaat's short stories. The International Fiction Review, 18(2), $108-112$.

Seymour-Jorn, C. (2011). Cultural criticism in Egyptian women's writing. New York: Syracuse University Press.

Shaaban, B. (2009). Voices revealed: Arab women novelists, 1898-2000. Boulder and London: Lynne Rienner Publishers, Inc.. 